\title{
SIFAT ORGANOLEPTIK HARD CANDY SUSU DENGAN JENIS GULA BERBEDA
}

\author{
Dian Prayogi \\ Program Diploma Kepariwisataan Universitas Merdeka Malang1 \\ Jl. Bandung No. 1 Malang
}

Korespodensi dengan Penulis:

Dian Prayogi: Telp: 08563522996

E-mail: dianprayogi87@yahoo.com

\begin{abstract}
Hard candy is non-crystalline candy which is cooked with high temperature. This research aim is to find out the quality of organoleptic. Data was analyzed using variance investigation and DMRT. There was a real difference from hedonic quality test results. The result from hedonic test showed that hard candy milk with sugar cane was preferred flavor, the preferred color was hard candy milk with palm sugar, preferred texture was sugar cane, preferred clarity was palm sugar. Different kind of sugar will produce hard candy milk with real difference of flavor, color, texture and clarity. It is influenced by differences in the amount of sucrose and ash content on any kind of sugar.
\end{abstract}

Key words: Hard Candy, Sugar, Organoleptic

Permen merupakan salah satu produk pangan yang banyak digemari oleh masyarakat umum karena mempunyai bentuk, warna serta rasa yang beragam. Secara umum, permen yang banyak beredar dikalangan masyarakat berjenis permen keras atau hard candy yang memiliki tekstur keras dan penampakan yang bening. Permen atau dalam bahasa inggrisnya candy berasal dari bahasa Arab quan yang artinya gula. Hal ini disebabkan komponen utama permen adalah gula yang diberi cita rasa dan dapat mempertahankan bentuknya dalam waktu yang lama dan dapat dicetak 
menurut bentuk-bentuk yang diinginkan (Hidayat, 2004)

Permen adalah suatu produk yang umumnya diharapkan dapat mempertahankan bentuknya dalam waktu yang cukup lama, dapat dicetak menurut bentuk-bentuk yang diinginkan dan tidak rusak, baik karena pengaruh kimiawi atau mikrobiologi, sebelum permen tersebut dikonsumsi (Tjokroadikoesoema,1986).

Candy atau permen menurut jenisnya dikelompokkan menjadi dua macam yaitu permen kristalin (krim) dan permen non kristalin (amorphus). Permen kristalin biasanya mempunyai rasa yang khas dan apabila dimakan terdapat rasa krim yang mencolok, contoh permen kristalin adalah fondant dan fudge. Permen non kristalin (amorphous) terkenal dengan sebutan "without form", bedasarkan teksturnya dibedakan menjadi hard candy, chewy candy, gum dan jellies (Farida, 2008).

Bahan dasar pada pembuatan hard candy adalah gula, sirup glukosa, air, pewarna dan flavour (Purwanto, 2002). Bahan pemanis dalam pembuatan hard candy adalah sukrosa, gula dari tebu atau bit. Pada temperatur ruang sekitar dua bagian gula dapat larut dalam satu bagian air. Jika larutan didinginkan tanpa proses agitasi menjadi superjenuh. Pada saat didinginkan dan disertai agitasi, sukrosa akan mengkristal. Proses pengkristalan dapat menjadi cepat dan besar jika terjadi penambahan sukrosa ke larutan superjenuh. Konsentrasi terbesar pada sukrosa dapat menjadi larut oleh kenaikan temperatur pada air. Semakin tinggi sukrosa semakin tinggi pula titik didih larutan. Hal ini dapat digunakan untuk mengontrol derajat atau tingkatan air dalam produksi gula pada saat titik didih dan konsentrasi sukrosa. Konstrasi larutan tinggi, pendinginan, menjadikan tingkat super jenuh yang tinggi dan mengeras (Potter, dkk. 1986)

Gula adalah suatu istilah umum yang sering diartikan bagi setiap karbohidrat yang digunakan sebagai pemanis, tetapi dalam industri pangan biasanya digunakan untuk menyatakan sukrosa yang diperoleh dari bit atau tebu (Buckle,dkk. 1987) Selain berbahan dasar gula, komponen flavour juga sangat penting dalam pembuatan hard candy. Flavour yang 
digunakan dalam pembuatan hard candy ini adalah susu yang juga berfungsi sebagai pengganti cairan. Susu adalah suatu sekresi yang komposisinya sangat berbeda dari komposisi darah yang merupakan asal susu. Misalnya lemak susu, casein, laktosa yang disintesa oleh alveoli dalam ambing, tidak terdapat di tempat lain manapun dalam tubuh sapi (Muchtadi,dkk. 1993).

Susu merupakan emulsi lemak dalam air yang mengandung garamgaram mineral, gula dan protein. Kisaran komposisi paling besar terjadi pada kandungan lemak. Hal ini disebabkan karena kadar lemak susu sangat dipengaruhi baik oleh faktor internal maupun eksternal (Muchtadi,dkk. 1993)

Bahan utama dalam pembuatan hard candy adalah gula yang akan membentuk struktur dasar hard candy. Jenis gula yang sering digunakan adalah sukrosa (gula pasir) dan glukosa. Dalam penelitian yang dilakukan gula yang digunakan adalah gula aren, gula kelapa dan gula tebu.

Gula aren adalah gula yang dihasilkan dari nira aren (Arenga pinnata) yang mempunyai warna coklat kekuning-kuningan. Gula kelapa yang juga dikenal sebagai gula jawa adalah gula yang dihasilkan dari penguapan nira pohon kelapa (Cocos nucifera), gula ini dapat bewarna coklat muda, coklat tua atau coklat kehitaman (Issoesetiyo, 2001). Gula tebu adalah gula yang dihasilkan dari tanaman tebu (Sacharum officinarum) dan digunakan sebagai pemanis alami, gula ini dapat berwarna putih yang mempunyai bentuk kristal putih (gula pasir) dan bewarna coklat kemerahan (Suryanto, 2008).

Penggunaan ketiga jenis gula tersebut dalam penelitian ini disebabkan karena gula aren, gula kelapa dan gula tebu mempunyai kandungan sukrosa yang mendekati taraf kemanisan normal untuk sukrosa yaitu $100 \%$. Ketiga jenis gula tersebut juga mudah didapatkan dipasaran dan harganya relatif terjangkau sehingga sesuai jika digunakan untuk berwirausaha.

Bedasarkan latar belakang di atas, penelitian yang dilakukan untuk hard candy susu dengan menggunakan gula aren, gula kelapa dan gula tebu untuk mengetahui adanya perbedaan yang dihasilkan dari berbagai jenis 
gula yang mempunyai jumlah tingkat sukrosa yang berbeda.Semakin tinggi sukrosa, hard candy yang dihasilkan semakin tidak bening dan jika semakin rendah sukrosa, hard candy yang dihasilkan tidak terlalu keras dan lengket, karena sukrosa merupakan bahan utama dalam pembuatan hard candy yang akan membentuk struktur dasar hard candy yang meliputi warna, rasa, tekstur dan kebeningan.

Hasil dari penelitian ini, diharapkan akan didapatkan variasi hard candy susu yang baru dan disukai konsumen sehingga dapat digunakan sebagai sarana untuk berwirausaha.

\section{METODE}

Penelitian yang dilakukan merupakan penelitian eksperimen dengan jenis gula berbeda. Gula yang digunakan adalah gula aren, gula kelapa dan gula tebu. Pengulangan dilakukan tiga kali. Pengujian dilakukan terhadap sifat organoleptik yang meliputi uji mutu hedonik dan uji hedonik terhadap rasa, warna, tekstur, dan kebeningan hard candy susu. Rancangan penelitian dapat dilihat pada tabel di bawah ini :
Tabel 1. Rancangan Penilitian

\begin{tabular}{cccc}
\hline \multirow{2}{*}{ Pengulangan } & $\begin{array}{c}\text { Gula } \\
\text { Aren }\end{array}$ & $\begin{array}{c}\text { Gula } \\
\text { Kelapa }\end{array}$ & $\begin{array}{c}\text { Gula } \\
\text { Tebu }\end{array}$ \\
\cline { 2 - 4 } & $\mathrm{A}$ & $\mathrm{B}$ & $\mathrm{C}$ \\
\hline 1 & $\mathrm{~A}_{1}$ & $\mathrm{~B}_{1}$ & $\mathrm{C}_{1}$ \\
\hline 2 & $\mathrm{~A}_{2}$ & $\mathrm{~B}_{2}$ & $\mathrm{C}_{2}$ \\
\hline 3 & $\mathrm{~A}_{3}$ & $\mathrm{~B}_{3}$ & $\mathrm{C}_{3}$ \\
\hline
\end{tabular}

Keterangan :

1 : Pengulangan 1

2 : Pengulangan 2

3 : Pengulangan 3

A : Gula Aren

B : Gula Kelapa

C: Gula Tebu

Instrumen yang digunakan adalah format penilaian uji mutu hedonik dan uji hedonik. Uji mutu hedonik menggunakan format penilaian terhadap rasa, warna, tekstur dan kebeningan. Pengisian format dilakukan dengan memberikan tanda $(\sqrt{ })$ pada jawaban yang sesuai menurut panelis. Teknik yang digunakan adalah teknik scoring. Skor yang digunakan dalam penelitian berkisar antara 1-4. Instrumen yang digunakan untuk uji hedonik berupa angket. Panelis diminta untuk memilih hard candy yang paling disuka dari hasil perlakuan yang digunakan.

Data penelitian diperoleh dari hasil pengisian format penilaian uji organoleptik yaitu uji mutu hedonik dan uji hedonik. Dalam penelitian ini 
peneliti menggunakan panelis agak terlatih. Kriteria panelis agak terlatih adalah panelis yang mengetahui sifatsifat sensorik dari contoh yang dinilaikan karena mendapat penjelasan atau sekedar latihan. Panelis agak terlatih dianggap cukup jika jumlahnya 15-20 orang. Bedasarkan penjelasan tersebut, maka peneliti memilih panelis dari mahasiswa DIII Tata Boga Universitas Negeri Malang angkatan 2005-2006 sebanyak 20 orang.

Data penelitian diperoleh dari hasil pengisian format penilaian uji mutu hedonik dan uji hedonik yang meliputi warna, rasa, tekstur dan kebeningan hard candy susu dengan gula aren, gula kelapa dan gula tebu. Data yang diperoleh dianalisis dengan menggunakan Analisis Sidik Ragam untuk menggambarkan perbedaan warna, rasa, tekstur dan kebeningan hard candy susu. Data yang dianalisis menggunakan sidik ragam terdapat perbedaan nyata maka analisis tersebut dilanjutkan dengan Duncan's Multiple Range Test (DMRT). Tujuan DMRT adalah untuk mengetahui perbedaan pada masing-masing formulasi. Data yang diperoleh dianalisis dengan menggunakan persentase dengan rumus $\frac{f}{n} \times 100 \%$ dimana $f$ adalah jumlah kesukaan panelis dan $n$ adalah jumlah panelis.

\section{HASIL DAN PEMBAHASAN}

Pada penelitian Tahap I dilakukan uji coba untuk menentukan formulasi yang tepat untuk setiap bahan pada pembuatan hard candy susu. Formulasi yang diuji coba yaitu jumlah cairan yang digunakan sama dengan jumlah gula jadi formulasinya 100 cc susu, 75 gr glukosa dan 100 gr untuk setiap jenis gula. Bedasarkan hasil penelitian tersebut didapatkan hard candy dengan tekstur yang tidak terlalu keras dan lengket, hal ini disebabkan karena meningkatnya kadar air pada hard candy sehingga hard candy lebih bersifat higroskopis, sehingga pada penelitian utama dilakukan penelitian tentang hard candy susu dengan formulasi jumlah cairan lebih sedikit dibandingkan dengan jumlah gula. Formulasi yang digunakan yaitu 80 cc susu, 75 gr sirup glukosa dan 100 gr untuk setiap jenis gula. 


\section{A. Hasil dan Pembahasan Uji Mutu} Hedonik Hard Candy Susu

\section{Uji Mutu Hedonik Rasa Hard}

\section{Candy Susu}

Bedasarkan hasil analisis dari uji mutu hedonik hard candy susu dengan jenis gula berbeda diketahui nilai rerata rasa hard candy susu yang tertinggi diperoleh dari perlakuan $\mathrm{C}$ dengan nilai rerata 3,66 yaitu dengan rasa manis. Nilai rerata yang diperoleh dari perlakuan B adalah 2,88 yaitu cukup manis. Sedangkan nilai rerata yang diperoleh dari perlakuan A adalah 2,06 yaitu agak manis.

Untuk melihat perbedaan rasa hard candy susu dengan jenis gula berbeda dapat dilihat pada tabel berikut ini :

Tabel 2. Analisis Sidik Ragam Rasa Hard Candy Susu dengan Jenis Gula Berbeda

\begin{tabular}{lllllll}
\hline Sumber Keragaman & $\mathrm{Db}$ & $\mathrm{JK}$ & $\mathrm{KT}$ & F hitung & & \multicolumn{2}{l}{ F Tabel } \\
\cline { 5 - 7 } & & & & & $5 \%$ & $1 \%$ \\
\hline Perlakuan & 2 & 66,32 & 33,16 & $53,48^{* *}$ & 3,07 & 4,79 \\
Kelompok & 59 & 29,40 & 0,49 & & & \\
Galat & 118 & 73,35 & 0,62 & & & \\
\hline Total & 179 & 169,07 & 34,27 & & & \\
\hline
\end{tabular}

Keterangan :

* : : : Berbeda pada taraf 5\% : Nyata

** : Berbeda pada taraf $1 \%$ : Sangat Nyata

Tabel di atas menunjukkan bahwa hard candy susu yang menggunakan jenis gula berbeda menghasilkan rasa yang berbeda sangat nyata. Hal ini diketahui dari $F_{\text {hitung }}(53,48)>F_{\text {tabel }}$ $(4,79)$ yang berarti terdapat perbedaan sangat nyata pada taraf $1 \%$. Analisis dilanjutkan dengan Duncan's Multiple Range Test (DMRT). Hasil analisis DMRT seperti pada tabel berikut ini :
Tabel 3. Hasil DMRT Uji Mutu Hedonik Rasa Hard Candy Susu

\begin{tabular}{llll}
\cline { 1 - 3 } db Error & $\mathbf{2}$ & \multicolumn{3}{l}{$\mathbf{3}$} \\
\cline { 1 - 3 } SSR 5 \% & 0,28 & 0,29 & \\
\cline { 1 - 3 } SSR 1 \% & 0,36 & 0,38 & \\
\cline { 1 - 3 } Perlakuan & A $(2,06)$ & $\mathrm{B}(2,88)$ & $\mathrm{C}(3,66)$ \\
\hline $\mathrm{A}(2,06)$ & - & $0,82^{* *}$ & $1,6^{* *}$ \\
\hline $\mathrm{B}(2,88)$ & - & - & $0,78^{* *}$ \\
\hline $\mathrm{C}(3,66)$ & - & - & - \\
\hline
\end{tabular}

Keterangan :

* $\quad$ : Berbeda pada taraf 5\% : Nyata

** : Berbeda pada taraf $1 \%$ : Sangat Nyata

A : Menggunakan gula aren

B : Menggunakan gula kelapa

C : Menggunakan gula tebu 
mempunyai rasa manis, tidak berbau,

Hasil uji DMRT pada tabel di atas menunjukkan perlakuan A berbeda sangat nyata dengan perlakuan B $(0,82)$. Perlakuan A berbeda sangat nyata dengan perlakuan C $(1,6)$. Perlakuan B berbeda sangat nyata dengan perlakuan $C(0,78)$.

Hasil analisis tersebut menunjukkan bahwa semakin tinggi kandungan sukrosa maka rasa yang dihasilkan semakin manis. Adanya perbedaan rasa pada hard candy susu dipengaruhi oleh komposisi sukrosa pada setiap jenis gula. Dalam pembuatan hard candy, sukrosa berfungsi untuk memberikan rasa manis dan kelembutan yang mempunyai daya larut yang tinggi (Hidayat, 2004). Sukrosa utama yang digunakan dalam industri pangan umumnya dapat mengkristal dan tidak larut dalam air (Winarno, 2002).

\section{Uji Mutu Hedonik Warna Hard Candy Susu}

Bedasarkan hasil analisis dari uji mutu hedonik hard candy susu dengan jenis gula berbeda

diketahui nilai rerata warna hard candy susu yang tertinggi diperoleh dari perlakuan A dengan nilai rerata 3,33 yaitu dengan warna coklat cerah. Nilai rerata yang diperoleh dari perlakuan B adalah 2,5 yaitu coklat cukup cerah. Sedangkan nilai rerata yang diperoleh dari perlakuan $\mathrm{C}$ adalah 1,4 yaitu coklat.

Untuk melihat perbedaan warna hard candy susu dengan jenis gula berbeda dapat dilihat pada tabel berikut ini :

Tabel 4. Analisis Sidik Ragam Warna Hard Candy Susu dengan Jenis Gula Berbeda

\begin{tabular}{|c|c|c|c|c|c|c|}
\hline \multirow[t]{2}{*}{ Sumber Keragaman } & \multirow[t]{2}{*}{$\mathrm{Db}$} & \multirow[t]{2}{*}{$\mathrm{JK}$} & \multirow[t]{2}{*}{ KT } & \multirow[t]{2}{*}{ F hitung } & \multicolumn{2}{|c|}{ F Tabel } \\
\hline & & & & & $5 \%$ & $1 \%$ \\
\hline Perlakuan & 2 & 112,85 & 56,43 & $91,01^{* *}$ & 3,07 & 4,79 \\
\hline Kelompok & 59 & 24,24 & 0,41 & & & \\
\hline Galat & 118 & 38,41 & 0,32 & & & \\
\hline Total & 179 & 175,5 & 57,16 & & & \\
\hline \multicolumn{7}{|l|}{ Keterangan: } \\
\hline $\begin{array}{ll}* & \text { : Berbeda pac } \\
* * & \text { : Berbeda pac }\end{array}$ & $\begin{array}{l}\text { Nya } \\
\text { San }\end{array}$ & Jyata & & & & \\
\hline
\end{tabular}

Tabel di atas, menunjukkan bahwa hard candy susu yang menggunakan jenis gula berbeda menghasilkan warna yang berbeda sangat nyata. Hal 
ini diketahui dari $F_{\text {hitung }}(91,01)>F_{\text {tabel }}$ (4.79) yang berarti terdapat perbedaan sangat nyata pada taraf $1 \%$. Analisis dilanjutkan dengan Duncan's Multiple Range Test (DMRT). Hasil analisis DMRT seperti pada tabel berikut ini :

Tabel 5. Hasil DMRT Uji Mutu Hedonik Warna Hard Candy Susu

\begin{tabular}{llll}
\cline { 1 - 3 } db Error & $\mathbf{2}$ & $\mathbf{3}$ & \\
\cline { 1 - 3 } SSR 5 \% & 0,19 & 0,20 & \\
\cline { 1 - 3 } SSR 1 \% & 0,25 & 0,26 & \\
\hline Perlakuan & C $(1,4)$ & B $(2,5)$ & A $(3,33)$ \\
\hline C $(1,4)$ & - & $1,1^{* *}$ & $1,93^{* *}$ \\
\hline B $(2,5)$ & - & - & $0,83^{* *}$ \\
\hline A $(3,33)$ & - & - & - \\
\hline
\end{tabular}

Keterangan :

* $\quad$ : Berbeda pada taraf 5\% : Nyata

** : Berbeda pada taraf $1 \%$ : Sangat Nyata

A : Menggunakan gula aren

B : Menggunakan gula kelapa

C : Menggunakan gula tebu

Hasil uji DMRT pada tabel di atas, menunjukkan bahwa perlakuan A berbeda sangat nyata dengan perlakuan B $(0,83)$. Perlakuan A berbeda sangat nyata dengan perlakuan C (1,93). Perlakuan B berbeda sangat nyata dengan perlakuan C $(1,1)$.

Hasil analisis tersebut menunjukkan bahwa kandungan kadar abu yang rendah pada gula akan menghasilkan hard candy susu dengan warna coklat cerah. Adanya perbedaan warna pada hard candy susu dipengaruhi oleh kandungan kadar abu pada setiap jenis gula. Kandungan kadar abu yang tinggi akan mengakibatkan peningkatan inversi dan pewarnaan selama pemasakan (Farida, 2008).

Pada hard candy susu yang menggunakan gula tebu, warna yang dihasilkan coklat walaupun kandungan kadar abu pada gula tebu lebih rendah dibandingkan dengan gula kelapa. Hal ini disebabkan karena pada gula tebu masih terdapat kandungan molases yang menyebabkan warna coklat kehitaman yang mengakibatkan peningkatan inversi dan pewarnaan selama pemasakan.

\section{Uji Mutu Hedonik Tekstur Hard Candy Susu}

Bedasarkan hasil analisis dari uji mutu hedonik hard candy susu dengan jenis gula berbeda diketahui nilai rerata tekstur hard candy susu yang tertinggi diperoleh dari perlakuan $C$ dengan nilai rerata 3,76 yaitu dengan tekstur keras. Nilai rerata yang diperoleh dari perlakuan B adalah 3,03 yaitu cukup keras. Sedangkan nilai rerata yang 
diperoleh dari perlakuan A adalah 2,5 yaitu kurang keras.
Untuk melihat perbedaan tekstur hard candy susu dengan jenis gula berbeda dapat dilihat pada tabel berikut ini :

Tabel 6. Analisis Sidik Ragam Tekstur Hard Candy Susu dengan Jenis Gula Berbeda

\begin{tabular}{lllllll}
\hline Sumber Keragaman & Db & JK & KT & F hitung & \multicolumn{2}{c}{ F Tabel } \\
\cline { 6 - 7 } & & & & & $5 \%$ & $1 \%$ \\
\hline Perlakuan & 2 & 48,53 & 24,26 & $134,77^{* *}$ & 3,07 & 4,79 \\
Kelompok & 59 & 20,2 & 0,34 & & & \\
Galat & 118 & 21,47 & 0,18 & & & \\
\hline Total & 179 & 90,2 & 24,78 & & & \\
\hline
\end{tabular}

Keterangan :

* $\quad$ : Berbeda pada taraf $5 \%$ : Nyata

** : : Berbeda pada taraf $1 \%$ : Sangat Nyata

Tabel di atas menunjukkan bahwa hard candy susu menggunakan jenis gula berbeda menghasilkan tekstur dengan tingkat kekerasan yang berbeda sangat nyata. Hal ini diketahui dari $F_{\text {hitung }}$ $(134,77)>F_{\text {tabel }}(4,79)$ yang berarti terdapat perbedaan sangat nyata pada taraf $1 \%$. Analisis dilanjutkan dengan Duncan's Multiple Range Test (DMRT). Hasil analisis DMRT seperti pada tabel berikut ini :

Tabel 7. Hasil DMRT Uji Mutu Hedonik Tekstur Hard Candy Susu

\begin{tabular}{llll}
\hline db Error & $\mathbf{2}$ & $\mathbf{3}$ & \\
\cline { 1 - 3 } SSR 5 \% & 0,13 & 0,15 & \\
\cline { 1 - 3 } SSR 1 \% & 0,18 & 0,19 & \\
\hline Perlakuan & A $(2,5)$ & B $(3,03)$ & C $(3,76)$ \\
\hline A $(2,5)$ & - & $0,53^{* *}$ & $1,26^{* *}$ \\
\hline B $(3,03)$ & - & - & $0,73^{* *}$ \\
\hline C $(3,76)$ & - & - & - \\
\hline
\end{tabular}

Keterangan :

* $\quad$ : Berbeda pada taraf $5 \%$ : Nyata
** : Berbeda pada taraf $1 \%$ : Sangat Nyata

A : Menggunakan gula aren

B : Menggunakan gula kelapa

C : Menggunakan gula tebu

Hasil uji DMRT pada tabel di atas, menunjukkan bahwa perlakuan A berbeda sangat nyata dengan perlakuan B $(0,53)$. Perlakuan A berbeda sangat nyata dengan perlakuan C (1,26). Perlakuan B berbeda sangat nyata dengan perlakuan $\mathrm{C}(0,73)$.

Hasil analisis tersebut menunjukkan bahwa bahwa semakin tinggi kandungan sukrosa maka tekstur yang dihasilkan semakin keras. Jumlah kandungan sukrosa yang semakin besar akan meningkatkan konsistensi dari hard candy sehingga akan 
membentuk tekstur keras dan kompak.

Konsentrasi terbesar pada sukrosa dapat menjadi larut oleh kenaikan temperatur pada air. Semakin tinggi sukrosa semakin tinggi pula titik didih larutan. Hal ini dapat digunakan untuk mengontrol derajat atau tingkatan air dalam produksi gula pada saat titik didih dan konsentrasi sukrosa. Konsentrasi larutan tinggi akan menjadikan tingkat larutan super jenuh yang tinggi dan tekstur yang mengeras (Potter, dkk:1986).

\section{Uji Mutu Hedonik Kebeningan Hard Candy Susu}

Bedasarkan hasil analisis dari uji mutu hedonik hard candy susu dengan jenis gula berbeda diketahui nilai rerata kebeningan hard candy susu yang tertinggi diperoleh dari perlakuan $\mathrm{A}$ dengan nilai rerata 3,71 yaitu dengan tekstur bening. Nilai rerata yang diperoleh dari perlakuan $\mathrm{B}$ adalah 3 yaitu cukup bening. Sedangkan nilai rerata yang diperoleh dari perlakuan C adalah 1,76 yaitu kurang bening. Untuk melihat perbedaan kebeningan hard candy susu dengan jenis gula berbeda dapat dilihat pada tabel berikut ini

Tabel 8. Analisis Sidik Ragam Kebeningan Hard Candy Susu dengan Jenis Gula Berbeda

\begin{tabular}{|c|c|c|c|c|c|c|}
\hline \multirow{2}{*}{ Sumber Keragaman } & \multirow[t]{2}{*}{$\mathrm{Db}$} & \multirow{2}{*}{ JK } & \multirow{2}{*}{ KT } & \multirow{2}{*}{ F hitung } & \multicolumn{2}{|c|}{ F Tabel } \\
\hline & & & & & $5 \%$ & $1 \%$ \\
\hline Perlakuan & 2 & 116,75 & 58,37 & $149,67^{* *}$ & 3,07 & 4,79 \\
\hline Kelompok & 59 & 18,33 & 0,31 & & & \\
\hline Galat & 118 & 46,59 & 0,39 & & & \\
\hline Total & 179 & 181,67 & 59,07 & & & \\
\hline \multicolumn{7}{|l|}{ Keterangan : } \\
\hline $\begin{array}{l}\text { : Berbeda pa } \\
: \text { Berbeda pa }\end{array}$ & $\begin{array}{l}\text { tara } \\
\text { tara }\end{array}$ & $\begin{array}{l}\text { Nyata } \\
\text { Sangat }\end{array}$ & & & & \\
\hline
\end{tabular}

Tabel di atas menunjukkan bahwa hard candy susu yang menggunakan jenis gula yang berbeda menghasilkan kebeningan yang berbeda sangat nyata. Hal ini diketahui dari Fhitung $(149,67)>F_{\text {tabel }}(4,79)$ yang berarti terdapat perbedaan sangat nyata pada taraf $1 \%$. Analisis dilanjutkan dengan Duncan's Multiple Range Test (DMRT). Hasil analisis DMRT seperti pada tabel berikut ini : 
Pada hard candy susu yang

Tabel 9. Hasil DMRT Uji Mutu Hedonik Kebeningan Hard Candy Susu

\begin{tabular}{llll}
\cline { 1 - 3 } db Error & $\mathbf{2}$ & $\mathbf{3}$ & \\
\cline { 1 - 3 } SSR 5 \% & 0,22 & 0,23 & \\
\cline { 1 - 3 } SSR 1 \% & 0,29 & 0,30 & \\
\hline Perlakuan & C $(1,76)$ & B $(3)$ & A $(3,71)$ \\
\hline C $(1,76)$ & - & $1,24^{* *}$ & $1,95^{* *}$ \\
\hline B $(3)$ & - & - & $0,71^{* *}$ \\
\hline A $(3,71)$ & - & - & - \\
\hline
\end{tabular}

Keterangan :

* : : Berbeda pada taraf $5 \%$ : Nyata

** : Berbeda pada taraf $1 \%$ : Sangat Nyata

A : Menggunakan gula aren

B : Menggunakan gula kelapa

C : Menggunakan gula tebu

Hasil uji DMRT pada tabel di atas, menunjukkan bahwa perlakuan A berbeda sangat nyata dengan perlakuan B $(0,71)$. Perlakuan A berbeda sangat nyata dengan perlakuan C $(1,95)$. Perlakuan B berbeda sangat nyata dengan perlakuan $\mathrm{C}(1,76)$.

Hasil analisis tersebut menunjukkan bahwa kandungan kadar abu yang rendah pada gula akan menghasilkan hard candy yang bening. Kandungan kadar abu yang tinggi akan mengakibatkan peningkatan inversi, pewarnaan dan penembusan selama pemasakan sehingga memperbanyak gelembung udara yang terperangkap dalam masa gula (Farida, 2008). menggunakan gula tebu kebeningan yang dihasilkan agak bening walaupun kandungan kadar abu pada gula tebu lebih rendah dibandingkan dengan gula kelapa. Hal ini disebabkan karena tingginya kandungan sukrosa pada gula tebu akan menyebabkan hard candy susu menjadi tidak bening. Kandungan sukrosa yang tinggi akan dapat mengakibatkan hard candy mengkristal sehingga cahaya tidak dapat menembus langsung. Kristalisasi dalam produk-produk ini berakibat mengurangi penampilan yang jernih seperti kaca dan membentuk masa yang kabur (Buckle,dkk.1987).

\section{B.Hasil dan Pembahasan Uji}

\section{Hedonik Hard Candy Susu}

\section{Uji Hedonik Rasa Hard Candy Susu}

Bedasarkan hasil yang diperoleh dapat diketahui bahwa hard candy susu dengan perlakuan A (gula aren), panelis yang menyatakan suka 8,33\% (sebagian kecil panelis), cukup suka 40\% (kurang dari setengah jumlah panelis), agak suka 33,3\% (kurang dari 
setengah jumlah panelis) dan kurang suka 18,33\% (sebagian kecil panelis).

Hard candy susu dengan perlakuan B (gula kelapa), panelis yang menyatakan suka 11,67\% (sebagian kecil panelis), cukup suka 36,67\% (kurang dari setengah jumlah panelis), agak suka $45 \%$ (kurang dari setengah jumlah panelis) dan kurang suka $6,66 \%$ (sebagian kecil panelis)

Hard candy susu dengan perlakuan C (gula tebu), panelis yang menyatakan suka 58,33\% (lebih dari setengah jumlah panelis), cukup suka 38,33\% (kurang dari setengah jumlah panelis), agak suka 3,33\% (sebagian kecil panelis) dan kurang suka $0 \%$ (tak seorangpun panelis).

\section{Uji Hedonik Warna Hard Candy Susu}

Bedasarkan hasil yang diperoleh dapat diketahui bahwa hard candy susu dengan perlakuan A (gula aren), panelis yang menyatakan suka $68,33 \%$ (lebih dari setengah jumlah panelis), cukup suka 26,67\% (kurang dari setengah jumlah panelis), agak suka 3,33\% (sebagian kecil panelis) dan kurang suka 1,67\% (sebagian kecil panelis).
Hard candy susu dengan perlakuan B (gula kelapa), panelis yang menyatakan suka $8,33 \%$ (sebagian kecil panelis), cukup suka 50\% (setengah panelis), agak suka $31,66 \%$ (kurang dari setengah jumlah panelis) dan kurang suka 10\% (sebagian kecil panelis).

Hard candy susu dengan perlakuan C (gula tebu), panelis yang menyatakan suka 5\% (sebagian kecil panelis), cukup suka 25\% (sebagian kecil panelis), agak suka 40\% (kurang dari setengah jumlah panelis) dan kurang suka $21,6 \%$ (sebagian kecil panelis).

\section{Uji Hedonik Tekstur Hard Candy Susu}

Bedasarkan hasil yang diperoleh dapat diketahui bahwa hard candy susu dengan perlakuan A (gula aren), panelis yang menyatakan suka $5 \%$ (sebagian kecil panelis), cukup suka 28,33\% (sebagian kecil panelis), agak suka 48,33\% (kurang dari setengah jumlah panelis) dan kurang suka 18,33\% (sebagian kecil panelis)

Hard candy susu dengan perlakuan B (gula kelapa), panelis yang menyatakan suka 23,33\% (sebagian kecil panelis), cukup suka 43,33\% 
(kurang dari setengah jumlah panelis), agak suka 25\% (sebagian kecil panelis) dan kurang suka 1,67\% (sebagian kecil panelis)

Hard candy susu dengan perlakuan C (gula aren), panelis yang menyatakan suka $61,67 \%$ (lebih dari setengah jumlah panelis), cukup suka 33,33\% (kurang dari setengah jumlah panelis), agak suka 3,33\% (sebagian kecil panelis) dan kurang suka 0\% (tak seorangpun panelis).

\section{Uji Hedonik Kebeningan Hard Candy Susu}

Bedasarkan hasil yang diperoleh dapat diketahui bahwa Hard candy susu dengan perlakuan A (gula aren), panelis yang menyatakan suka $68,33 \%$ (lebih dari setengah jumlah panelis), cukup suka 26,67\% (kurang dari setengah jumlah panelis), agak suka $1,67 \%$ (sebagian kecil panelis) dan kurang suka3,33\% (sebagian kecil panelis).

Hard candy susu dengan perlakuan B (gula kelapa), panelis yang menyatakan suka 21,67\% (sebagian kecil panelis), cukup suka 51,67\% (lebih dari setengah jumlah panelis), agak suka 20\% (sebagian kecil panelis) dan kurang suka 6,67\% (sebagian kecil panelis)

hard candy susu dengan perlakuan C (gula tebu), panelis yang menyatakan suka 3,33\% (sebagian kecil panelis), cukup suka 20\% (sebagian kecil panelis), agak suka 51,67\% (lebih dari setengah jumlah panelis) dan kurang suka 25\% (sebagian kecil panelis).

\section{KESIMPULAN}

Bedasarkan hasil dan pembahasan tentang hard candy susu dapat disimpulkan bahwa: (1) terdapat perbedaan rasa hard candy susu untuk setiap perlakuan. Hard candy susu dengan rasa manis diperoleh dari hard candy yang menggunakan gula tebu, (2) terdapat perbedaan warna hard candy susu untuk setiap perlakuan. Hard candy susu dengan warna coklat cerah diperoleh dari hard candy yang menggunakan gula aren, (3) terdapat perbedaan tekstur hard candy susu untuk setiap perlakuan. Hard candy susu dengan tekstur keras diperoleh dari hard candy yang menggunakan gula tebu, (4) terdapat perbedaan kebeningan hard candy susu untuk setiap perlakuan. Hard candy susu yang bening diperoleh dari hard candy 
yang menggunakan gula aren, (5) rasa hard candy susu yang disukai panelis adalah hard candy susu dengan menggunakan gula tebu, (6) warna hard candy susu yang disukai panelis adalah hard candy susu dengan menggunakan gula aren, (7) tekstur hard candy susu yang disukai panelis adalah hard candy susu dengan menggunakan gula tebu, dan (8) kebeningan hard candy susu yang disukai panelis adalah hard candy susu dengan menggunakan gula aren.

Bedasarkan penelitian yang telah dilakukan, peneliti menyarankan pada peneliti selanjutnya untuk meneliti tentang formulasi dari setiap jenis gula sehingga didapatkan produk yang dapat memenuhi syarat karakteristik dari hard candy

\section{DAFTAR PUSTAKA}

Buckle,

K.A.,R.A.Edwards,G.H.Fleet,M.

Wootton. 1987. Food Science. Diterjemahkan oleh Hari Purnomo dan Adiono. 1987. Ilmu Pangan. Jakarta : Universitas Indonesia Press

Faridah, Anni. 2008. Patisery. Jakarta : Direktorat Pembinaan Sekolah Menengah Kejuruan
Hidayat, Nur. 2004. Membuat Permen Jelly. Surabaya : Trubus Agrisarana.

Issoesetiyo., 2001. Gula Kelapa Produk Industri Hilir Sepanjang Masa. Surabaya: Arkola

Muchtadi. 1993. Ilmu Pengetahuan Bahan Pangan. Bogor : IPB

Potter, Norman N., Hotchkiss, Josep H. 1986. Food Science. New York USA : Chapman and Hall.

Purwanto, Wahyu. 2002. Hard Candy dengan Flavor Dari Minyak Kelapa. ((online) http : www.goegle.co.id, diakses 10 Juni 2009)

Suryanto, 2008. Seputar Gula. ((online) http: : www.goegle.co.id, diakses 6 Maret 2009)

Tjokroadikoesoema, S. 1993. HFS dan Industri Ubi Kayu Lainnya. Jakarta : PT. Grmaedia Pustaka Utama 
ISSN(p) : $1410-7252$ ISSN(e): $2541-5859$

Vol. 2 No. 01 Desember 2016 